University of Nebraska - Lincoln

DigitalCommons@University of Nebraska - Lincoln

Faculty Publications: Department of Entomology

October 2006

\title{
Comparative Sensitivity of Freshwater Algae to Atrazine
}

C. K. Lockert

University of Nebraska-Lincoln

Kyle D. Hoagland

University of Nebraska-Lincoln, khoagland1@unl.edu

Blair D. Siegfried

University of Nebraska-Lincoln, bsiegfried1@ufl.edu

Follow this and additional works at: https://digitalcommons.unl.edu/entomologyfacpub

Part of the Entomology Commons

Lockert, C. K.; Hoagland, Kyle D.; and Siegfried, Blair D., "Comparative Sensitivity of Freshwater Algae to Atrazine" (2006). Faculty Publications: Department of Entomology. 66.

https://digitalcommons.unl.edu/entomologyfacpub/66

This Article is brought to you for free and open access by the Entomology, Department of at DigitalCommons@University of Nebraska - Lincoln. It has been accepted for inclusion in Faculty Publications: Department of Entomology by an authorized administrator of DigitalCommons@University of Nebraska - Lincoln. 


\title{
Comparative Sensitivity of Freshwater Algae to Atrazine
}

\author{
C. K. Lockert, ${ }^{1}$ K. D. Hoagland, ${ }^{1}$ and B. D. Siegfried ${ }^{2}$ \\ ${ }^{1}$ School of Natural Resources, University of Nebraska-Lincoln, Lincoln, NE 68583-0758, \\ USA \\ 2 Department of Entomology, 306 Plant Industry Building, University of Nebraska-Lincoln, \\ Lincoln, NE 68583-0816, USA \\ Corresponding author: B. D. Siegfried
}

Widespread use of environmentally persistent herbicides has led to increasing concern over their impact on aquatic ecosystems and nontarget organisms. The triazine herbicide atrazine (6-chloro- $N$-ethyl- $N^{1}$-[1-methylethyl]-1,3,5-triazine-2,4diamine) remains one of the most heavily used pesticides worldwide, and was the second most commonly used conventional pesticide in the U.S. agricultural market in 2001 (http://www.epa.gov/oppbead1/pestsales/01pestsales/usage2001_2.htm). Atrazine is an $S$-triazine herbicide that targets the photosynthetic process to control broadleaf weeds. Due to the moderate solubility $\left(33 \mathrm{mg} / \mathrm{L}\right.$ at $\left.22^{\circ} \mathrm{C}\right)$ and relative persistence of atrazine in water (Solomon et al. 1996), contamination of surface waters as a result of non-point source inputs is a threat to lakes and streams. Atrazine contamination has been documented year-round in the Platte River in Nebraska (Nelson et al. 1999), and concentrations as great as $691 \mu \mathrm{g} / \mathrm{L}$ have been observed in first-order stream samples collected during post-planting storm events (Langan et al. 1993). The effect of surface-water contamination on nontarget organisms is especially important for freshwater algal communities, given their role as the predominant primary producers in most lotic environments (Herman et al. 1986). Moreover, freshwater algae form the base of aquatic food webs and changes in algal community structure and composition may have cascading effects on other components of the community due to changes in food availability and important community-level interactions.

A number of laboratory, microcosm and field studies have examined atrazine toxicity in freshwater algae (DeNoyelles et al. 1982; Herman et al. 1986; Solomon et al. 1996; Tang et al. 1997; Fairchild et al. 1998). From these studies, it is generally recognized that certain algal species are more sensitive to atrazine (DeNoyelles et al. 1982; Tang et al. 1997; Fairchild et al. 1998). Green algae generally are more susceptible to atrazine than diatoms (Tang et al. 1997). However, relatively few algal divisions and species have been tested for their response to atrazine exposure. 
The overall objective of this research was to determine the differential sensitivity of atrazine to algal species common in freshwater ecosystems in the Midwest. Several of the previously described studies examined a small number of algal species and divisions, focusing on green algae, cyanobacteria (also known as bluegreen algae), and diatoms. We used a greater number and variety of species to define tolerance to atrazine over a broader range of freshwater algae. Additionally, cell size was examined as a possible determinant of differential toxicity to atrazine among algal species.

\section{Materials and Methods}

Alga taxa representative of streams and rivers from across the agricultural Midwest were selected from culture collections maintained in our laboratory (Green algae: Ankistrodesmus falcatus (Corda) Ralfs, Chlorella vulgaris Beyerinck, and Staurastrum cristatum (Nag.) Arch; Diatoms: Cyclotella meneghiniana Kütz., and Nitzschia palea (Kütz.) W. Smith; Cryptomonad: Cryptomonas ovata Ehr. Additional cultures were obtained from Carolina Biological Supply (Cyanobacteria: Arthrospira sp. and Euglenoid: Euglena gracilis Klebs) and the University of Texas Culture Collection (Cyanobacteria: Synechococcus sp.). The diatoms, green algae, and cryptomonad were grown in WC freshwater medium (Nichols 1973; Tang et al. 1997), the cyanobacteria in Allen's medium (Fogg et al. 1973), and the euglenoid in soil-water extract (Nichols 1973). Different media were used to achieve high growth rates for each species. All of the algae were grown under unialgal, axenic conditions in $25 \times 150$ - $\mathrm{mm}$ glass culture tubes, and were transferred to fresh growth medium every $14 \mathrm{~d}$ to maintain high growth rates. Cultures were incubated at $21^{\circ} \mathrm{C}$ with an alternate $12: 12 \mathrm{~h}$ light:dark cycle under cool white fluorescent lights $\left(100 \mu \mathrm{mol} \mathrm{m} \mathrm{m}^{-2}\right)$.

Technical grade atrazine (99\% purity) was purchased from Chem Service (West Chester, PA, USA). A $1 \mathrm{mg} / \mathrm{ml}$ stock solution was prepared by dissolving atrazine in $100 \%$ ethanol which had been filter sterilized using a 0.22-pm Millex-GS filter unit (Milli-Q, Bedford, MA, USA). Serial dilutions (10:1) of the primary stock provided secondary atrazine stock solutions. These stock solutions were added to autoclaved growth medium at nominal concentrations of $0,0.01,0.1,1.0,10,100$, and $1000 \mu \mathrm{g}$ atrazine/l. Atrazine concentrations were measured at the University of Nebraska Water Sciences Laboratory $(0.20 \mu \mathrm{g} / \mathrm{L}$ detection limit $)$ using gas chromatography-mass spectrometry (GC-MS) analysis (Nelson et al. 1999). Initial concentrations of atrazine were $<0.20(0.01),<0.20(0.10), 0.97(1.0), 10.44$ (10.0), 106.2 (100), and $1159 \mu \mathrm{g} / \mathrm{L}$ (1000) (nominal concentrations in parentheses). This range of atrazine concentrations encompasses environmentally realistic levels reported in the literature for midwestern aquatic habitats (Jurgensen and Hoagland 1990; Thurman et al. 1991). The final concentration of ethanol did not exceed $0.001 \%$. Ethanol was added to the control medium at the same concentration, to insure that effects were due to atrazine exposure. The atrazine-treated 
growth medium was dispensed into autoclaved culture tubes $(39 \mathrm{ml})$ and subsequently inoculated with $1 \mathrm{ml}$ of algal cell suspension (7-10 days old). Five replicate tubes were used for each herbicide concentration, providing five replications for each species at each treatment level (35 tubes per species). All algal transfers were performed aseptically in a laminar flow hood. In vivo fluorescence of chlorophyll $\boldsymbol{a}$ was monitored non-destructively with a fluorometer (Turner Designs, Sunnyvale, CA, USA, model 10-AU) on days $0,1,3,5$ using a 436-nm excitation filter and a 680-nm emission filter. Growth rates in cell doubling per day (dpd) were calculated based on the fluorometer readings using the following formula: $\ln$ $\mathrm{Ft}_{2}-\ln \mathrm{Ft}_{1} /\left(\mathrm{t}_{2}-\mathrm{t}_{1}\right)$ In 2 ; where $\mathrm{Ft}_{1}=$ fluorescence at time 1 and $\mathrm{Ft}_{2}=$ fluorescence at time 2 (Guillard 1973).

Cell counts were performed to validate the accuracy of the values generated by fluorescence readings. In a separate experiment, samples were withdrawn from treatment cultures for microscopic enumeration of cells on days 1,3 , and 5 to obtain growth rates based on cell density (cells/ml). For each sample, thirty random fields of view were counted in a Sedgewick-Rafter cell at 200x using a Nikon Labophot-2 microscope. Cell counts were performed for five replicates at each concentration for each species.

At least 25 cells from exponential-phase control cultures, randomly selected, were measured to determine mean cell volume for each species. Cell volume was calculated according to appropriate geometric shapes and formulae of Hillebrand et al. (1999). The shapes used were $\boldsymbol{A}$. falcatus, cylinder plus two cones; Arthrospira sp., each cell in a filament is a cylinder; $C$. vulgaris, sphere; $C$. ovata, prolate spheroid; $C$. meneghiniana, cylinder; E. gracilis, ellipsoid; $N$. palea, prizm on elliptic base; $S$. cristatum, pyramid on triangular/rectangular base; and Synechococcus sp., cylinder. Cell dimensions were measured under oil immersion using an ocular micrometer-equipped Nikon inverted fluorescent microscope.

Mean growth rates (cell doubling per day) for each treatment were compared to controls, and percent inhibition of algal growth was calculated using $100 *(1-\mathrm{T} /$ $\mathrm{C}$ ); where $\mathrm{T}=$ mean growth rate of treated cultures based on fluorescence and $\mathrm{C}$ $=$ mean growth rate of control cultures. These calculations indicate that differential sensitivity was most evident on day 5 , on which growth rates were high and the length of exposure was long enough to show true effects of the herbicide. Therefore, further analyses were performed on day 5 data only. Differential toxicity was compared at $100 \mu \mathrm{g}$ atrazine/L because this was the lowest concentration at which significant deviations from control cultures were observed. Statistically significant effects of $100 \mu \mathrm{g} / \mathrm{L}$ atrazine exposure on growth, for the different algal species, were determined using ANOVA in conjunction with Duncan's multiple range test (SAS Institute 1994) with 95\% confidence intervals $(\mathrm{P}<0.05)$. The relationship between atrazine toxicity and cell size (volume) was evaluated by linear regression. 


\section{Results and Discussion}

There was no significant effect of atrazine concentrations up to $10 \mu \mathrm{g} / \mathrm{L}$ on the growth of any of the species tested (data not shown). Differential susceptibility among the species was evident at $100 \mu \mathrm{g} / \mathrm{L}$ atrazine with growth inhibition ranging from $<1.0 \%$ (E. gracilis) to $75.0 \%$ (C. vulgaris) (Fig. 1). At $100 \mu \mathrm{g} / \mathrm{L}$, green algae were strongly inhibited relative to the other algae indicating a generally higher sensitivity to atrazine of this division. Cyanobacteria were moderately inhibited by atrazine, while the diatoms, cryptomonad and euglenoid did not exhibit significant inhibition. The response of the three green algal taxa to atrazine was significantly greater $(\mathrm{P}<0.05)$ than those of the diatoms, the cryptomonad, and the euglenoid. Furthermore, the response of the euglenoid to atrazine was significantly $(\mathrm{P}<0.05)$ lower than all of the other algal divisions tested. Growth rates decreased similarly within algal divisions, but differed significantly among algal divisions. The highest atrazine concentration tested $(1000 \mu \mathrm{g} / \mathrm{L})$ was extremely toxic to most species with $>75 \%$ growth inhibition, except for E. gracilis and Arthrospira, which were relatively unaffected at this high concentration. In a separate experiment, comparisons between cell density and chlorophyll a measurements generally indicated consistency between the two methods, especially at atrazine concentrations $>10 \mu \mathrm{g} / \mathrm{L}$ (data not shown).

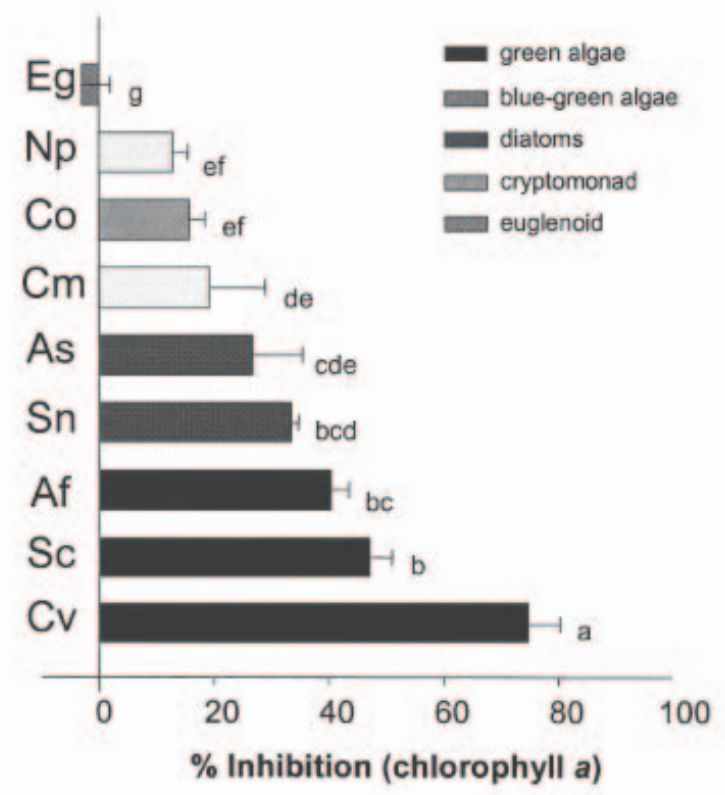

Figure 1. Mean atrazine inhibition of chlorophyll $a$ on day 5 at $100 \mu \mathrm{g} / \mathrm{L}$. Differences among treatment means were determined by analysis of variance $(\mathrm{P}<0.05)$. Bars followed by the same letter are not significantly different $(\mathrm{P}<0.05$; Duncan's multiple range test). Ankistrodesmus falcatus (Af), Arthrospira sp. (As), Chlorella vulgaris $(\mathrm{Cv})$, Cryptomonas ovata (Co), Cyclotella meneghiniana $(\mathrm{Cm})$, Euglena gracilis (Eg), Nitzschia palea $(\mathrm{Np})$, Staurastrum cristatum $(\mathrm{Sc})$, and Synechococcus sp. (Sn).

There was a wide range in cell volume among the species tested. Cell volume ranged from 43.3 to $7529.0 \mu \mathrm{m}^{3}$ for the green algae, 81.66 and $378.5 \mu^{3}$ for diatoms, 2.52 and $3.66 \mu \mathrm{m}^{3}$ for cyanobacteria, $1037.5 \mu \mathrm{m}^{3}$ for the cryptomonad, and $1547.4 \mu \mathrm{m}^{3}$ for the euglenoid. Individual cell volume varied among species and in general, cell size was not defined by algal division. The relationship between cell 
volume and atrazine toxicity was not significant $\left(\mathrm{r}^{2}=0.02 \mathrm{P}=0.70\right)$; however, in general, smaller cells were more susceptible than larger cells (Fig. 2). The relationship between cell size and atrazine toxicity was significant only at the $\mathrm{P}=$ 0.10 level $\left(\mathrm{r}^{2}=0.38\right)$ when the much larger species, $S$. cristatum, was not included in the analysis; indicating that the relationship between cell size and atrazine toxicity was not well defined among the algal species examined.

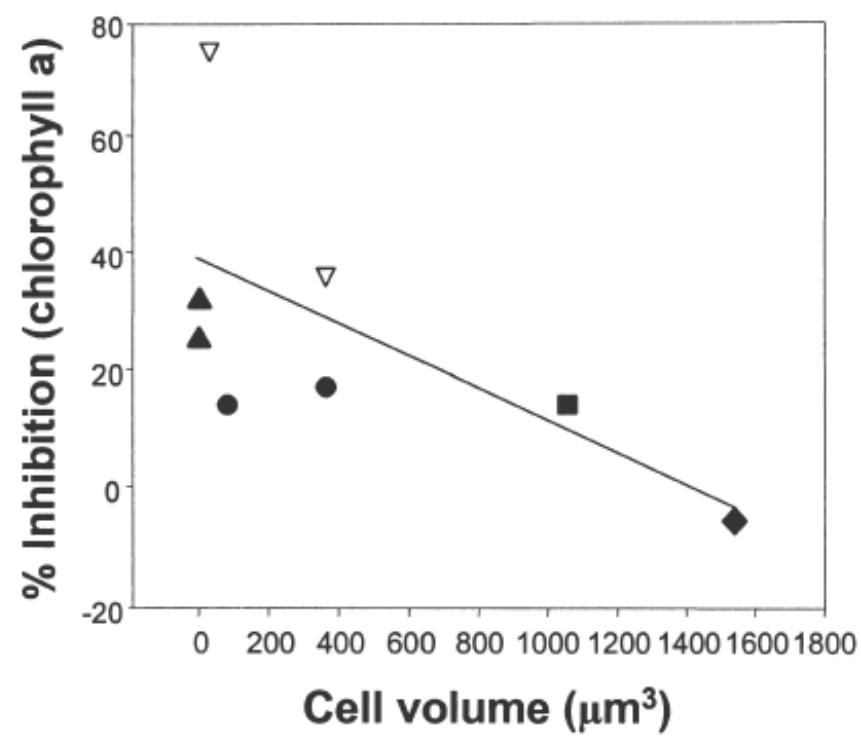

Figure 2. Correlation between cell size $\left(\mu \mathrm{m}^{3}\right)$ and atrazine $(\%$ inhibition of in vivo fluorescence of chlorophyll $a)$. Green algae $(\nabla)$, cyanobacteria $(\boldsymbol{\Delta})$, diatoms $(\bullet)$, cryptomonad $(\mathbf{\bullet})$, and the euglenoid $(\diamond)$. Linear regression results with all species included were $\mathrm{r}^{2}=0.02, \mathrm{P}=0.70$. With the much larger green alga, S. cristatum, not included, the linear regression results were $\mathrm{r}^{2}=0.38, \mathrm{P}=0.10$.

Results of this study indicate that atrazine is differentially toxic to freshwater algae and that algal division may dictate sensitivity. Nine species were tested, representing five algal divisions, and green algae were the most sensitive to atrazine exposure. The tolerance of two species, C. ovata and E. gracilis, representatives of the Cryptomonad and Euglenoid divisions respectively, were previously unknown. The results indicate both species are relatively tolerant to atrazine exposure, and appear to be less sensitive than both green algae and cyanobacteria. Little effect on algal growth was detected at atrazine concentrations $\leq 10 \mu \mathrm{g} / \mathrm{L}$. DeNoyelles et al. (1982) reported inhibition of some species at atrazine concentrations as low as $1.0 \mu \mathrm{g} / \mathrm{L}$. Our data are consistent with the findings of Huber (1993), who concluded that at least $20 \mu \mathrm{g} / \mathrm{L}$ atrazine was necessary for generating clear-cut effects. Additionally, our results support previous studies in which green algae appear very sensitive to atrazine, while cyanobacteria and diatoms appear more tolerant. Fairchild et al. (1998) reported that green algae were typically more sensitive than cyanobacteria to atrazine, metribuzin, alachlor, or metolachor. Tang et al. (1997) found lower $\mathrm{EC}_{50}$ values for green algae than diatoms after several days of exposure to atrazine. 
Previous research indicated a significant relationship between cell size and sensitivity to atrazine. Tang et al. (1998a) observed a high correlation between cell volume and atrazine toxicity for four species of green algae and four diatoms. A similar pattern was evident in the present study (i.e., smaller cells were generally more susceptible than larger cells), but the relationship was not significant when a larger number of algal divisions are included. The cyanobacteria were very small $\left(<5 \mu \mathrm{m}^{3}\right)$, yet were more tolerant than the larger green algae. Green algae represented a wide range of cell volumes, but were consistently the most susceptible, for the divisions examined. These observations suggest that factors other than cell size may be more important in determining atrazine sensitivity of freshwater algae.

In higher plants, differences in response to herbicides among species generally depends on factors influencing the amount of herbicide reaching the site of action, including differential uptake, translocation, and metabolism. The mechanism of differential sensitivity in freshwater algae is less clear. Tang et al. (1998b) found differences among algal species in the activity of glutathione-s-transferase, an enzyme associated with atrazine detoxification in vascular plants, yet the different rates of metabolism were not sufficient to explain the differential responses of the algae to atrazine. Tang et al. (1998a) found that the uptake of atrazine by green algae was significantly greater than that of diatoms, and that green algae had greater bioconcentration factors as well. However, in that study, the strongest predictor of algal sensitivity was cell biovolume. Based on results of the present study, biovolume may be a contributing factor, but it appears likely that other factors also contribute to differential algal sensitivity.

Acknowledgments. This study was funded by a grant from the United States Geological Survey, Section 104 program through the UNL Water Center. A contribution of the University of Nebraska Agricultural Research Division, Lincoln, NE 68583. Journal Series No. 13644.

\section{References}

DeNoyelles F, Kettle WD, Sinn DE (1982) The responses of plankton communities in experimental ponds to atrazine, the most heavily used pesticide in the United States. Ecology 63: 1285-1293

Fairchild JF, Ruessler DS, Carlson AR (1998) Comparative sensitivity of five species of macrophytes and six species of algae to atrazine, metribuzin, alachlor, and metoachlor. Environ Toxicol Chem 17: 1830-1834

Fogg GE, Stewart WDP, Fay P, Walsby AE (1973) The Blue-Green Algae. Academic, New York p 129-142 
Guillard RRL (1973) Division rates. In: Stein JR (ed) Handbook of Phycological Methods: Culture Methods and Growth Measurements. Cambridge University, London $\mathrm{p}$ 289-312

Herman D, Kaushik NK, Solomon KR (1986) Impact of atrazine on periphyton in freshwater enclosures and some ecological consequences. Can J Fish Aquat Sci 43: $1917-1925$

Hillebrand H, Dürselen CD, Kirschtel D, Pollinger U, Zohary T (1999) Biovolume calculation for pelagic and benthic microalgae. J Phycol 35: 403-424

Huber W (1993) Ecotoxicological relevance of atrazine in aquatic systems. Environ Toxicol Chem 12: 1865-1881

Jurgensen TA, Hoagland KD (1990) Effects of short-term pulses of atrazine on attached algal communities in a small stream. Arch Environ Contam Toxicol 19: 617-623

Langan MM, Hoagland KD, Everson AR (1993) Pesticide levels in storm runoff from agricultural stream sites with different riparian buffer strips. Proc Platte River Basin Ecosystem Sym, December 7-8, pp. 223-233

Nelson KJ, Hoagland KD, Siegfried BD (1999) Chronic effects of atrazine on tolerance of a benthic diatom. Environ Toxicol Chem 18: 1038-1045

Nichols HW (1973) Growth media-freshwater. In: Stein JR (ed) Handbook of Phycological Methods: Culture Methods and Growth Measurements. Cambridge University, London, p 7-24

SAS Institute (1994) SAS/STAT@ User's Guide, Ver 6.0. Cary, NC, USA

Solomon KR, Baker DB, Richards RP, Dixon KR, Klaine SJ, La Point TW, Kendall RJ, Weisskopf CP, Giddings JM, Giesy JP, Hall LW Jr, Williams WM (1996) Ecological risk assessment of atrazine in North American surface waters. Environ Toxicol Chem 5: $31-76$

Tang JX, Hoagland KD, Siegfried BD (1997) Differential toxicity of atrazine to selected freshwater algae. Bull Environ Contam Toxicol 59: 631-637

Tang JX, Hoagland KD, Siegfried BD (1998a) Uptake and bioconcentration of atrazine by selected freshwater algae. Environ Toxicol Chem 17: 1085-1090

Tang JX, Hoagland KD, Siegfried BD (1998b) Glutathione-s-transferase and in vitro metabolism of atrazine in freshwater algae. Pest Biochem Physiol 59: 155-161

Thurman EM, Goolsby DA, Meyer MT, Kolpin DW (1991) Herbicides in surface waters of the midwestern United States: The effect of spring flush. Environ Sci Technol 25: 1794-1796 